\title{
Possible role of TORCH agents in congenital malformations in Gorgan, northern Islamic Republic of Iran
}

\author{
M.J. Golalipour, ${ }^{1}$ B. Khodabakhshi' ${ }^{2}$ and E. Ghaemi ${ }^{3}$
}

الدور المحتمل لعوامل المقوّسات القُندية والحصبة الألمانية والفيروسة المضخمة للخلايا في التشوهات الخلقية في

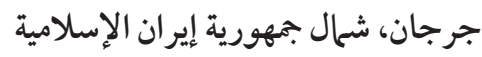

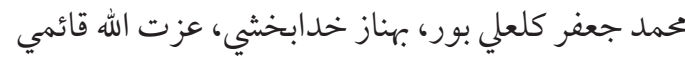
الخلاصسة: أجرى الباحثون هذه الدر اسة الو صفية المستعرضة لاستقصاء تكرار العدوى بعو امل المقوَّسات القندية

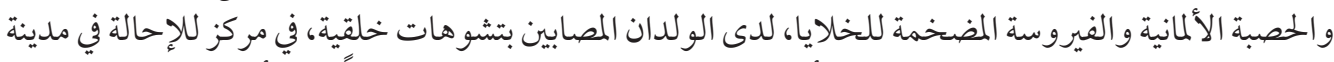

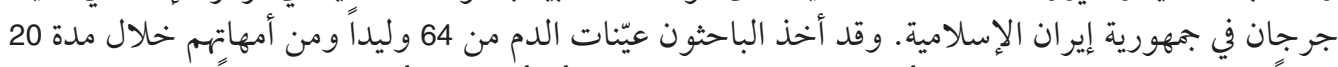

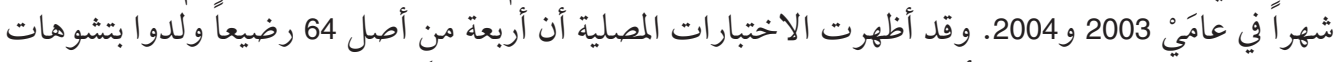

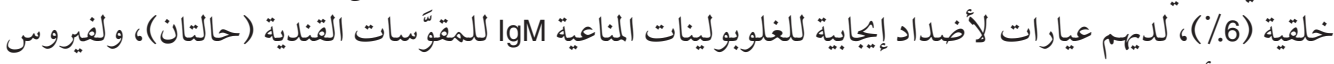

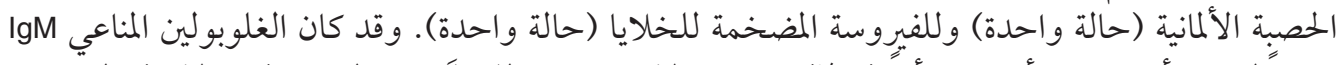

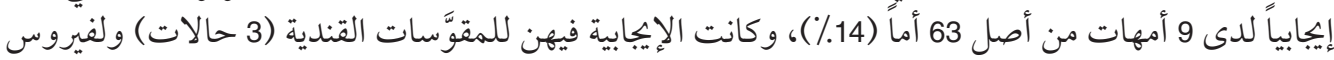

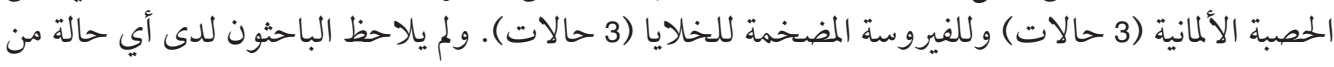

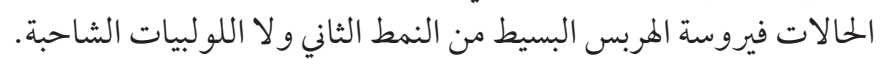

ABSTRACT This descriptive, cross-sectional study was carried out to explore the frequency of contamination with TORCH agents in neonates with congenital malformations in a referral centre in Gorgan city, Islamic Republic of Iran. Blood samples were taken from 64 neonates and their mothers over a 20-month period in 2003-04. Serologic tests showed that 4/64 infants born with congenital malformations (6\%) had positive IgM antibody titres for Toxoplasma gondii (2 cases), rubella virus (1 case) and cytomegalovirus ( 1 case). IgM was positive in 9/63 mothers (14\%), also for $T$. gondii ( 3 cases), rubella virus ( 3 cases) and cytomegalovirus (3 cases). No cases of herpes simplex virus type II or Treponema pallidum were found.

Rôle possible des agents «TORCH » dans les malformations congénitales à Gorgan (nord de la République islamique d'Iran)

RÉSUMÉ Cette étude descriptive transversale a été réalisée afin d'examiner la fréquence de la contamination par les agents TORCH chez les nouveau-nés présentant des malformations congénitales dans un centre spécialisé de Gorgan (République islamique d'Iran). Des prélèvements sanguins ont été effectués sur 64 nouveau-nés et leur mère pendant une période de 20 mois en 2003-2004. Les tests sérologiques ont montré que quatre nourrissons sur 64 nés avec des malformations congénitales (6\%) avaient des taux positifs d'anticorps de type lgM dirigés contre Toxoplasma gondii (2 cas), contre le virus de la rubéole (un cas) et contre le cytomégalovirus (un cas). Chez neuf mères sur 63 (14\%), les IgM étaient positifs à $T$. gondii (trois cas), au virus de la rubéole (trois cas) et au cytomégalovirus (trois cas). Aucun cas de virus de l'herpès de type 2 ou de Treponema pallidum n'a été détecté.

${ }^{1}$ Gorgan Congenital Malformations Research Centre; ${ }^{2}$ Department of Infectious Diseases; ${ }^{3}$ Department of Microbiology, Gorgan University of Medical Sciences, Gorgan, Islamic Republic of Iran (Correspondence to M.J.Golalipour: mjgolalipour@yahoo.com).

Received: 30/05/06; accepted: 31/10/06

المجلة الصحية لشرق المتوسط، منظمة الصحة العالمية، المجلد الخامس عشر، العدد Y، 9 +. 


\section{Introduction}

One of the important goals in medical research is determining the factors that can affect the health of mothers and their fetuses/neonates. Congenital malformations are important causes of infant morbidity, mortality and disability, and are found in approximately $2 \%-3 \%$ of neonates [1]. Congenital malformations have a direct impact on the family, and place a financial burden on medical, educational and support services. Treatment and rehabilitation of children with such malformations is also expensive, and complete recovery is usually impossible [2-5].

The causes of congenital malformations are varied and few studies have evaluated their etiology in neonates [4]. Previous studies have indicated that the prevalence of congenital malformation was 10.00 per 1000 in the north of the Islamic Republic of Iran [5] and the prevalence of neural tube defect was 3.12 per 1000 in this area [6].

Malformations can be divided into broad categories, one being malformations attributed to discrete environmental factors $[1,7]$. Infectious agents, as environmental factors, can create intrauterine infections leading to birth defects, abortion and stillbirth [8,9].

The TORCH agents-toxoplasmosis, other agents, rubella virus, cytomegalovirus (CMV) and herpes simplex virus (HSV)are the most important infectious agents that can cause congenital malformations. The infections in women are usually asymptomatic and chronic. Prevalence varies from one geographical area to another [10]. The social and reproductive issues - pregnancy wastage, cost of treatment and morbidity to the infant-make TORCH agents a major cause of concern. Many sensitive and specific tests are available for serological diagnosis of these agents. Complex ELISA tests for IgM antibodies against these infections are highly sensitive and specific [11].
There are a few reports about the role of infectious agents in birth defects [10-13] and there are different recommendations about screening with serology tests during pregnancy. This study was done to determine the frequency of contamination with infectious agents in neonates with congenital malformations born in a referral centre in Gorgan city (northern Islamic Republic of Iran) and their mothers.

\section{Methods}

This cross-sectional study was done on all neonates born with major congenital malformations during a 20-month period in Dezyani hospital, a referral gynaecology centre in Gorgan, in the north of the Islamic Republic of Iran during 2003-04.

All neonates delivered alive in this hospital during the study period were screened for congenital malformations including neural tube defects, cleft lip and palate and limb defects. The charts of neonates with birth defects were subsequently extracted for detailed study. Variables recorded included: date of birth, sex and type of malformation.

Blood samples were taken from the affected neonates and their mothers after obtaining permission from the parents and the hospital directors. Then a questionnaire on demographic characteristics, including age and parents' residence, was completed by interview for each case. Ethical approval was obtained from the Health Research Ethics Review Board at the University of Golestan, Gorgan.

Serum was prepared from the samples and serologic tests were done to determine IgM and IgG levels against rubella virus, $T$. gondii, CMV and HSV type II with ELISA tests (StarFax 303 ELISA reader and kits, Radiom Company). The cut-off values used were as follows: rubella IgG positive $>20$ $\mathrm{IU} / \mathrm{mL}$, rubella $\mathrm{IgM}$ positive $>10 \mathrm{IU} / \mathrm{mL}$;

المجلة الصحية لشرق المتوسط، منظمة الصحة العالمية، المجلد الخامس عشر، العدد ب، 9 +. 
T. gondii $\mathrm{IgG}$ and $\mathrm{IgM}$ positive $>50 \mathrm{IU} / \mathrm{mL}$; CMV IgG positive $>1.1$, CMV IgM positive $>15 \mathrm{IU} / \mathrm{mL} ; \mathrm{HSV}$ IgG positive $>1.1$ $\mathrm{IU} / \mathrm{mL}$, HSV IgM positive $>1.1 \mathrm{IU} / \mathrm{mL}$

For Treponema pallidum the rapid plasma reagin (RPR) test was used (Omega Co., Scotland). Flocculation of samples was considered a positive result.

\section{Results}

This study included 64 neonates $(46 \%$ males) and 63 mothers ( 1 mother delivered twins). Mean and standard deviation (SD) of maternal and paternal ages were 26.4 (SD 5.0) and 29.6 (SD 5.0) years respectively.

The frequency of IgM and IgG antibodies against TORCH agents in the sera of the neonates and mothers is shown in Tables 1 and 2. Of the 64 neonates with birth defects, $4(6 \%)$ were IgM positive against TORCH agents: 1 for rubella virus, 2 for $T$. gondii and 1 for CMV.

Of the 63 mothers, 9 (14\%) had positive IgM antibody titres for TORCH agents: 3 for T. gondii, 3 for rubella virus and 3 for CMV.
IgM against rubella virus was observed in 1 neonate and 3 mothers.

Tables 1 and 2 show that $62.5 \%$ of neonates with congenital malformations and $58.7 \%$ of mothers were positive for CMV IgG antibody. IgG antibody against $T$. gondii was positive in $38.1 \%$ of mothers and $35.9 \%$ of neonates, but $3.2 \%$ of neonates and $4.8 \%$ of mothers had positive IgM antibody for T. gondii. IgG and IgM against HSV type II in neonates and mothers were negative in all cases. The RPR test for Treponema pallidum was also negative in all mothers.

Table 3 shows the distribution of positive infections according to type of defect. Of the 4 neonates with major malformations who were positive for TORCH agents, 2 had neural tube defects, 1 had cleft plate and 1 had limb defects.

\section{Discussion}

In this study, positive IgM antibody against TORCH agents was found in $6 \%$ of neonates with congenital malformations. This is lower than in a study in Tabriz in the north-

\begin{tabular}{|c|c|c|c|c|c|c|}
\hline \multirow[t]{2}{*}{ Test } & \multicolumn{2}{|c|}{ Positive } & \multicolumn{2}{|c|}{ Borderline } & \multicolumn{2}{|c|}{ Negative } \\
\hline & No. & $\%$ & No. & $\%$ & No. & $\%$ \\
\hline \multicolumn{7}{|c|}{ Herpes simplex virus } \\
\hline $\lg G$ & 0 & 0.0 & 0 & 0.0 & 64 & 100.0 \\
\hline $\lg M$ & 0 & 0.0 & 0 & 0.0 & 64 & 100.0 \\
\hline \multicolumn{7}{|c|}{ Rubella virus } \\
\hline $\lg G$ & 51 & 79.7 & 8 & 12.5 & 5 & 7.8 \\
\hline $\lg M$ & 1 & 1.6 & 0 & 0.0 & 63 & 98.4 \\
\hline \multicolumn{7}{|c|}{ Cytomegalovirus } \\
\hline $\lg G$ & 40 & 62.5 & 5 & 7.8 & 19 & 29.7 \\
\hline $\lg M$ & 1 & 1.6 & 0 & 0.0 & 63 & 98.4 \\
\hline \multicolumn{7}{|c|}{ Toxoplasma gondii } \\
\hline $\lg G$ & 23 & 35.9 & 3 & 4.7 & 38 & 59.4 \\
\hline $\lg M$ & 2 & 3.2 & 0 & 0.0 & 62 & 96.9 \\
\hline
\end{tabular}




\begin{tabular}{|c|c|c|c|c|c|c|}
\hline \multirow[t]{2}{*}{ Test } & \multicolumn{2}{|c|}{ Positive } & \multicolumn{2}{|c|}{ Borderline } & \multicolumn{2}{|c|}{ Negative } \\
\hline & No. & $\%$ & No. & $\%$ & No. & $\%$ \\
\hline \multicolumn{7}{|c|}{ Herpes simplex virus } \\
\hline $\lg G$ & 0 & 0.0 & 0 & 0.0 & 63 & 100.0 \\
\hline $\lg M$ & 0 & 0.0 & 0 & 0.0 & 63 & 100.0 \\
\hline \multicolumn{7}{|c|}{ Rubella virus } \\
\hline $\lg G$ & 53 & 84.1 & 4 & 6.3 & 6 & 9.5 \\
\hline $\lg M$ & 3 & 4.8 & 5 & 7.9 & 55 & 87.3 \\
\hline \multicolumn{7}{|c|}{ Cytomegalovirus } \\
\hline $\lg G$ & 37 & 58.7 & 7 & 11.1 & 19 & 30.2 \\
\hline $\lg M$ & 3 & 4.8 & 7 & 11.1 & 53 & 84.1 \\
\hline \multicolumn{7}{|c|}{ Toxoplasma gondii } \\
\hline $\lg G$ & 24 & 38.1 & 5 & 7.9 & 34 & 54.0 \\
\hline $\lg M$ & 3 & 4.8 & 4 & 6.3 & 56 & 88.9 \\
\hline \multicolumn{7}{|c|}{ Treponema pallidum } \\
\hline $\lg G$ & 0 & 0.0 & 0 & 0.0 & 63 & 100.0 \\
\hline $\lg M$ & 0 & 0.0 & 0 & 0.0 & 63 & 100.0 \\
\hline
\end{tabular}

west of the Islamic Republic of Iran with $32.5 \%$ [12]. This difference may be due to a higher prevalence of TORCH agents in pregnant mothers in Tabriz or to differences in sampling and study design.

Our findings showed that $41.3 \%$ of mothers were negative or borderline for antibodies against CMV which means that they are susceptible to $\mathrm{CMV}$ infection during pregnancy. Intrauterine $\mathrm{CMV}$ infection and prenatal CMV infection occur in $9.5 \%-22 \%$ of neonates [14]. CMV infection in pregnancy continues to be the leading problem as most primary maternal infections are missed due to the paucity of distinct clinical findings. Furthermore, it seems that there is an increasing role of reinfection with $\mathrm{CMV}$ (that also usually passes unnoticed) as an important etiologic factor in congenital CMV [15].

In this study, $62.5 \%$ of neonates had CMV IgG antibodies. Previous studies showed that fetal infection occurs in 5\% of pregnancies if primary CMV infection exists and $10 \%-15 \%$ of these infected fetuses will be delivered with important congenital

\begin{tabular}{|c|c|c|c|c|c|c|c|c|c|}
\hline \multirow[t]{2}{*}{ Defect } & \multicolumn{4}{|c|}{ IgM-positive neonates } & \multicolumn{4}{|c|}{ IgM-positive mothers } & \multirow{2}{*}{$\begin{array}{l}\text { Total no. of } \\
\text { anomalies }\end{array}$} \\
\hline & Toxo & $\begin{array}{c}\text { Rubella } \\
\text { virus }\end{array}$ & CMV & No. & Toxo & $\begin{array}{c}\text { Rubella } \\
\text { virus }\end{array}$ & CMV & No. & \\
\hline Neural tube defect & + & - & + & 2 & $3+$ & $2+$ & $2+$ & 7 & 32 \\
\hline Cleft palate & - & + & - & 1 & - & + & + & 2 & 14 \\
\hline Limb anomaly & + & - & - & 1 & - & - & - & 0 & 6 \\
\hline
\end{tabular}

Toxo = Toxoplasma gondii; CMV = cytomegalovirus . 
malformations [16,17]. Blackburn et al. reported CMV IgG antibody in up to $96 \%$ of pregnant women [18] but in our study $58.7 \%$ of the mothers tested positive.

In a study by Ebrahimpour et al. in Tabriz, $3.08 \%$ of neonates with congenital malformations were positive for CMV IgM antibody [12], but in the present study just 1 case $(1.6 \%)$ with congenital malformations was positive, perhaps due to a higher frequency of CMV infections in Tabriz. All mothers in the Tabriz study were positive for CMV IgG antibody, but in our study less than $60 \%$ of mothers tested positive for CMV IgG antibody.

In a study in a Turkish hospital on 128 pregnant women, $87.5 \%$ were $\mathrm{IgG}$ positive for CMV [19]. As Chiodo et al. reported, it is very hard to discriminate between primary infection and recurrent infection in pregnancy [20]. CMV infection may occur in the first trimester and cause congenital malformations, but at the time of delivery, due to the switching of IgM to IgG, it is difficult to determine the relationship between congenital malformations and CMV infection.

Sever et al. established a matched casecontrol study to evaluate the relationship between congenital malformations and serologic evidence of TORCH in mothers. However, they could not find any significant association [21].

In a study in the United States of America, all neonates with intrauterine growth disorder had CMV IgM negative results [22]. It was concluded that serologic screening for TORCH agents is not cost-effective. In the present study, $38.1 \%$ of mothers and $35.9 \%$ of neonatestested positive for $\mathrm{IgG}$ antibody against $T$. gondii, but $3.2 \%$ of neonates with congenital malformations and $4.8 \%$ of mothers tested positive for $\operatorname{IgM}$ antibody for $T$. gondii. Toxoplasmosis can be transmitted to the fetus up to 6 months after primary infection. The transmission rate is higher in the 3rd trimester, which can explain the higher rate of $T$. gondii IgM in neonates in the present study.

Ebrahimpour et al. in Tabriz reported anti-Toxoplasma IgG in $100 \%$ of mothers and neonates [12]. This difference from our study is likely due to geographical differences in the prevalence of toxoplasmosis. Kaur et al. in India reported positive IgG for T. gondii in $11.6 \%$ of mothers and recommended that screening tests for TORCH include toxoplasmosis [23]. However, an Irish study detected very few positive tests in screened samples and considered screening tests were not feasible [24].

Cao et al. studied TORCH serology in 2 groups, healthy mothers and mothers with abnormal conception, and reported Toxoplasma antibody in $16.6 \%$ and $11.1 \%$ respectively. They considered TORCH screening feasible [25].

No positive results for HSV type II were seen in our study compared with Ebrahimpour's team in Tabriz, who showed positivity for HSV type I and II IgG antibodies in all (40 cases) of mothers [12]. This difference could be due to different laboratory methods and social differences. Also, Kaur et al. reported a prevalence of $7 \%$ for HSV type II antibody IgG in India [23]. These differences need further investigation.

\section{Conclusion}

In this study IgM antibody against toxoplasmosis, rubella virus and CMV was positive in $14 \%$ of mothers and $6 \%$ of neonates. Screening tests for TORCH agents in pregnant mothers without a history of abnormal infants are not feasible, but in pregnant mothers with a history of abnormal conception or babies, serologic testing of both mothers and neonates could be useful for detecting malformations. 


\section{Acknowledgements}

We thank the Deputy of Research, Gorgan University of Medical Sciences, Dr Arezoo Mirfazeli, Dr Elham Mobasheri, Mrs
Hajizadeh, Mrs Hajilar and Mrs Sharifei. Special thanks to Dr Ali Rayej and Dr A.R. Mansourian for reviewing the English.

\section{References}

1. Kalter H, Warkany J. Congenital malformations. Etiologic factors and their role in prevention (first of two parts). New England journal of medicine, 1983, 308(8):424-31.

2. Chung CS et al. Congenital anomalies: mortality and morbidity, burden and classification. American journal of medical genetics, 1987, 27:505-23.

3. Waitzman NJ, Romano PS, Scheffler RM. Estimates of the economic costs of birth defects. Inquiry, 1994, 31:188-205.

4. American College of Medical Genetics Foundation. Evaluation of the newborn with single or multiple congenital anomalies: a clinical guideline [website] (www. health.state.ny.us/nysdoh/dpprd/main. htm, accessed 12 July 2008).

5. Golalipour MJ, Ahmadpour-Kacho M, Vakili MA. Congenital malformations at a referral hospital in Gorgan, Islamic Republic of Iran. Eastern Mediterranean health journal, 2005, 11:707-15.

6. Golalipour MJ, Vakili MA, Arya B. Neural tube defects in newborns in the SouthEast of the Caspian border [Gorgan, Iran 1998-2000]. Medical Journal of the Islamic Republic of Iran, 2003, 16:199203.

7. Sawardekar KP. Profile of major congenital malformations at Nizwa Hospital, Oman: 10-year review. Journal of paediatrics and child health, 2005, 41:323-30.

8. Klein JO, Remington JS. Infectious diseases of the fetus and newborn infant, 3rd ed. Philadelphia, Saunders, 1990:1-14.
9. Demmler GJ. Summary of a workshop on surveillance for congenital CMV diseases. Review of infectious diseases, 1993. 29:313-5.

10. Surpam RB et al. TORCH infection in women with bad obstetric history. Journal of obstetrics and gynecology of India, 2006, 56:41-3.

11. Malhotra VL et al. Comparison of enzyme linked immunosorbent assay and indirect haemagglutination test in serologic diagnosis of toxoplasmosis. Journal of communicable diseases, 1991, 23:154-6.

12. Ebrahimpour $S$ et al. The possible role of cytomegalovirus in induction of major congenital anomalies, stillbirth and intrauterine growth retardation. Medical journal of Tabriz University of Medical Sciences and Health Services, 2000, 48:3-8.

13. Thant $K Z$ et al. Active surveillance for congenital rubella syndrome in Yangon, Myanmar. Bulletin of the World Health Organization, 2006, 84:1-80.

14. Mladina N, Mehikić G, Pasić A. TORCH infekcije majki kao uzrok neonatalnog morbiditeta [TORCH infections in mothers as a cause of neonatal morbidity] Medicinski arhiv, 2000, 54:273-6.

15. Ornoy A. Intrauterine infections: introductory comments. Journal of reproductive toxicology, 2006, 21:343-4.

16. Weber BM, Born HJ. Laboratory diagnosis of congenital HCMV infections using polymerase chain reaction and shell viral culture. Infection, 1992, 30:45-7. 
17. Mark B et al. Congenital CMV infection and maternal antibody status. New England journal of medicine, 1992, 327:495-6.

18. Blackburn NK, Besselar TG, Schoub BD. Differentiation of primary CMV infection from reactivation using the urea denaturation test for measuring antibody avidity. Journal of medical virology, 1991, 33:6-9.

19. Ustaçelebi $S$ et al. Hamilelikte TORCH etkenlerine karsi antikorlarin saptanmasi [Detection of antibodies against TORCH agent during pregnancy]. Mikrobiyoloji bulteni, 1986, 20:1-8.

20. Chiodo $\mathrm{F}$ et al. Infective disease during pregnancy and their teratogenic effects. Annali dell'Istituto Superiore di Sanita, 1993, 29:57-67.

21. Sever JL et al. Perinatal "TORCH" infections identified by serology: correlation with abnormalities in the children through 7 years of age. International journal of epidemiology, 1992, 21:285-92.

22. Khan NA, Kazzi SN. Yield and costs of screening growth-retarded infants for TORCH infections. American journal of perinatology, 2000, 17:131-5.

23. Kaur R et al. Screening for TORCH infects in pregnant women: a report from Delhi. Southeast Asian journal of tropical medicine and public health, 1999, 30:284-6.

24. Cullen A et al. Current use of the TORCH screen in the diagnosis of congenital infection. Journal of infection, 1998, 36:185-8.

25. Cao Y, Qiu L, Zhang Q. [Study on the relationship between the history of abnormal pregnancy and TORCH infection in pregnant woman]. Zhonghua fu chan ke za zhi, 1999, 4:517-20 [in Chinese].

\section{Medical journals in the Region}

The WHO Eastern Mediterranean Regional Office publishes a list of medical journals in the Region at http://www.emro.who.int/emrjorlist/. Journals can be listed alphabetically by name or by country. Visitors to the site can also find a list of online journals published in Region 